\title{
Front Matter: Volume 11087
}

, "Front Matter: Volume 11087," Proc. SPIE 11087, Biosensing and Nanomedicine XII, 1108701 (3 October 2019); doi: 10.1117/12.2552531

SPIE Event: SPIE Nanoscience + Engineering, 2019, San Diego, California, United SPIE. States 


\title{
PROCEEDINGS OF SPIE
}

\section{Biosensing and Nanomedicine XII}

\author{
Hooman Mohseni \\ Massoud H. Agahi \\ Editors
}

11 August 2019

San Diego, California, United States

Sponsored and Published by

SPIE 
The papers in this volume were part of the technical conference cited on the cover and title page. Papers were selected and subject to review by the editors and conference program committee. Some conference presentations may not be available for publication. Additional papers and presentation recordings may be available online in the SPIE Digital Library at SPIEDigitalLibrary.org.

The papers reflect the work and thoughts of the authors and are published herein as submitted. The publisher is not responsible for the validity of the information or for any outcomes resulting from reliance thereon.

Please use the following format to cite material from these proceedings:

Author(s), "Title of Paper," in Biosensing and Nanomedicine XII, edited by Hooman Mohseni, Massoud H. Agahi, Proceedings of SPIE Vol. 11087 (SPIE, Bellingham, WA, 2019) Seven-digit Article CID Number.

ISSN: 0277-786X

ISSN: 1996-756X (electronic)

ISBN: 9781510628670

ISBN: 9781510628687 (electronic)

Published by

SPIE

P.O. Box 10, Bellingham, Washington 98227-0010 USA

Telephone +1 3606763290 (Pacific Time) · Fax +1 3606471445

SPIE.org

Copyright @ 2019, Society of Photo-Optical Instrumentation Engineers.

Copying of material in this book for internal or personal use, or for the internal or personal use of specific clients, beyond the fair use provisions granted by the U.S. Copyright Law is authorized by SPIE subject to payment of copying fees. The Transactional Reporting Service base fee for this volume is $\$ 21.00$ per article (or portion thereof), which should be paid directly to the Copyright Clearance Center (CCC), 222 Rosewood Drive, Danvers, MA 01923. Payment may also be made electronically through CCC Online at copyright.com. Other copying for republication, resale, advertising or promotion, or any form of systematic or multiple reproduction of any material in this book is prohibited except with permission in writing from the publisher. The CCC fee code is 0277$786 \times / 19 / \$ 21.00$.

Printed in the United States of America by Curran Associates, Inc., under license from SPIE.

Publication of record for individual papers is online in the SPIE Digital Library.

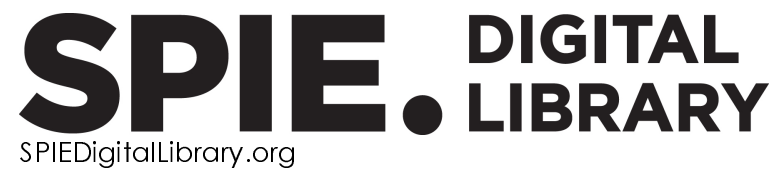

Paper Numbering: Proceedings of SPIE follow an e-First publication model. A unique citation identifier (CID) number is assigned to each article at the time of publication. Utilization of CIDs allows articles to be fully citable as soon as they are published online, and connects the same identifier to all online and print versions of the publication. SPIE uses a seven-digit CID article numbering system structured as follows:

- The first five digits correspond to the SPIE volume number.

- The last two digits indicate publication order within the volume using a Base 36 numbering system employing both numerals and letters. These two-number sets start with $00,01,02,03,04$, 05, 06, 07, 08, 09, OA, OB ... 0Z, followed by 10-1Z, 20-2Z, etc. The CID Number appears on each page of the manuscript. 


\title{
Contents
}

\author{
$\checkmark \quad$ Authors \\ vii Conference Committee
}

\section{BIOSENSING}

1108702 Direct detection of cancer biomarkers using plasmonics-based inverse Molecular Sentinel (iMS) nanobiosensors [11087-1]

\section{WEARABLE AND MOBILE BIOSENSORS}

11087 OE Detecting and discriminating between different types of bacteria with a low-cost smartphone based optical device and neural network models [1 1087-13]

BIO-IMAGING AND MICROSCOPY

11087 0J Radioluminescent fiber probes for radiotherapy dosimetry (Invited Paper) [1 1087-18]

\section{POSTER SESSION}

11087 ON Muller-matrix invariants of linear and circular birefringence of polycrystalline films of biological liquids pathologically and necrotic changed human bodies [1 1087-22]

11087 OP Methods and systems of diffuse tomography of optical anisotropy of biological layers [11087-24]

$110870 Q \quad$ Polarization correlometry of microscopic images of layers of biological tissues and films of biological liquids in the diagnostics of pressure of death [1 1087-25]

11087 OR Muller-matrix correlating invariants of phase and amplitude anistropy of biological layers [11087-26]

11087 OS Multifunctional polarization mapping system of networks of biological crystals in the diagnostics of pathological and necrotic changes of human organs [11087-27]

11087 OU Transition metal dichalcogenide material based tunneling field-effect transistor for label free bio-sensing application [1 1087-31]

$110870 Z$ Silver coated magnetic nanoparticles for enhanced nucleic acid detection [1 1087-37] 
$1108711 \quad$ Filter-free optofluidic micropipette devices for fluorescence sensing [11087-39]

1108712 Protein phosphorylation reagent concentration curves via Raman spectroscopy for real-time reaction monitoring in a microfluidic reactor [1 1087-40]

1108713 Differential components of Muller matrix partially depolarizing biological tissues in the diagnosis of pathological and necrotic changes [11087-43]

1108714 Polarization-phase reconstruction of polycrystalline structure of biological tissues [11087-44]

1108715 Use of carbon nanodots for visualization of the degenerative area of aricular cartilage [11087-45] 


\section{Authors}

Numbers in the index correspond to the last two digits of the seven-digit citation identifier (CID) article numbering system used in Proceedings of SPIE. The first five digits reflect the volume number. Base 36 numbering is employed for the last two digits and indicates the order of articles within the volume. Numbers start with 00, 01, 02, 03, 04, 05, 06, 07, 08, 09, OA, OB...0Z, followed by 10-1Z, 20-2Z, etc.

Arkhelyuk, A. D., OP, 13, 14

Bachinskyi, V. T., OP, OQ, 13

Balagurusamy, Venkat, OE

Bodnar, B. G., OS, 14

Bowie, Michelle L., 02

Campbell, Caroline A., 12

Casey, Abigail H. M., 12

Cheng, Li-Jing, OZ, 11

Chusan, Nyia E., 12

Crawford, Bridget M., 02

Darafsheh, Arash, OJ

Dillenberger, Donna, OE

Dovgun, A., OR

Drin, Ya., ON

Dubey, Prabhat Kumar, OU

Dubolazov, O. V., ON, OP, OQ, OR, OS, 13, 14

Dureja, Sahil, OE

Dvorjak, V., OQ, OS

Foglinskiy, S., OP, OS

Galochkin, O., OR

Garazdyuk, M., ON, OR

Golub, S., OR

Gorsky, M., ON

Grytsyuk, M., ON, OR

Gurina, $\mathrm{O} ., \mathrm{ON}$

Hoholeva, T., OQ

Kaushik, Brajesh Kumar, OU

Kovalchuk, M., OR

Kudva, Prabhakar, OE

Kumar, Ashwin Dhinesh, OE

Kvasniuk, D. I., 15

Ligman, Joseph, OE

Litvinenko, O., ON, OP, OQ

Liv, Ye, 0Z, 11

Maksimyak, A. P., 15

Maksimyak, P. P., 15

Martsenyak, I. V., OQ, OS

Motrich, A. V., OP, 13, 14

Olar, O. V., OP, 13, 14

Pavliukovich, O. V., OR, 13

Pavlyukovich, N., OR, 13

Penteleichuk, N., 14

Petrochak, O., OP

Pidkamin, L. Y., OP, 13, 14

Sakhnovskiy, M., OR

Sarkisova, YU., OQ, 14

Seewaldt, Victoria L., 02

Shaplavskiy, M. V., 14

Siu, Vince, OE
Soltys, I., ON

Talakh, M., ON

Tanyi, Ekembu K., 0Z, 11

Tomka, Yu., ON

Tong, Matt, OE

Triplett, Gregory E., 12

Ushenko, O., OQ, OS

Ushenko, YU., OR

Vanchulyak, O. Ya., OQ, OS

Vo-Dinh, Tuan, 02

Wang, Hsin-Neng, 02

Wang, Yi-Chieh, 0Z, 11

$\mathrm{Wu}, \mathrm{BO}, \mathrm{OZ}, 11$

Yatsko, O., ON

Zhytaryuk, $\vee ., O Q, O S$ 
Proc. of SPIE Vol. 11087 1108701-6 Downloaded From: https://www.spiedigitallibrary.org/conference-proceedings-of-spie on 26 Apr 2023
Terms of Use: https://www.spiedigitallibrary.org/terms-of-use 


\section{Conference Committee}

Symposium Chairs

Halina Rubinsztein-Dunlop, The University of Queensland (Australia)

Mark L. Brongersma, Geballe Laboratory for Advanced Materials

(GLAM) (United States), Stanford University (United States)

Symposium Co-chairs

Reuven Gordon, University of Victoria (Canada)

Natalia M. Litchinitser, Duke University (United States)

Conference Chairs

Hooman Mohseni, Northwestern University (United States)

Massoud H. Agahi, Harbor-UCLA Medical Center (United States) and Cedars-Sinai Medical Center (United States)

Conference Program Committee

Gert Cauwenberghs, University of California, San Diego (United States)

Philippe M. Fauchet, Vanderbilt University (United States)

Ryan M. Gelfand, CREOL, The College of Optics and Photonics, University of Central Florida (Canada)

David H. Gracias, Johns Hopkins University (United States)

Kimberly S. Hamad-Schifferli, Massachusetts Institute of Technology (United States)

Yu-Hwa Lo, University of California, San Diego (United States)

Omer G. Memis, Northwestern University (United States)

Masoud Panjehpour, Thompson Cancer Survival Center (United States)

Qimin Quan, Harvard University (United States)

Björn M. Reinhard, Boston University (United States)

Luisa Torsi, Università degli Studi di Bari Aldo Moro (Italy)

Adam T. Woolley, Brigham Young University (United States)

Session Chairs

1 Biosensing

Hooman Mohseni, Northwestern University (United States)

Ahmet Ali Yanik, University of California, Santa Cruz (United States) 
2 Neural Sensing

Pedram Mohseni, Case Western Reserve University (United States)

Changhuei Yang, Caltech (United States)

3 Wearable and Mobile Biosensors

Andrea M. Armani, The University of Southern California (United States)

David A. Borton, Brown University (United States)

4 Bio-Imaging and Microscopy

Hooman Mohseni, Northwestern University (United States)

Michael J. Sailor, University of California, San Diego (United States) 